\title{
Soil water dynamics and evapotranspiration of forage cactus clones under rainfed conditions
}

\author{
Thieres George Freire da Silva(1), Jorge Torres Araújo Primo(1), Magna Soelma Beserra de Moura(2), \\ Sérvulo Mercier Siqueira e Silva( ${ }^{(3)}$, José Edson Florentino de Morais ${ }^{(1)}$, Poliana de Caldas Pereira(4) \\ and Carlos André Alves de Souza ${ }^{(1)}$
}

\begin{abstract}
(1)Universidade Federal Rural do Pernambuco, Unidade Acadêmica de Serra Talhada, Caixa Postal 063, CEP 56900-000 Serra Talhada, PE,

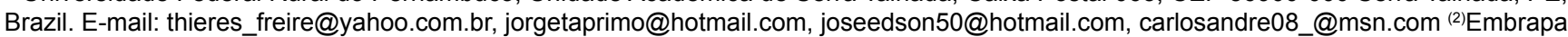
Semiárido, BR-428, Km 152, Zona Rural, Caixa Postal 23, CEP 56302-970 Petrolina, PE, Brazil. E-mail: magna.moura@embrapa.br (3)Instituto Agronômico de Pernambuco, BR 232, Km 253, CEP 56500-000 Arcoverde, PE, Brazil. E-mail: servulo.siqueira@ipa.br (4)Universidade Federal de Viçosa, Avenida Peter Henry Holfs, s/nº, CEP 36570-900 Viçosa, MG, Brazil. E-mail: po.caldas@hotmail.com
\end{abstract}

\begin{abstract}
The objective of this work was to evaluate soil water dynamics in areas cultivated with forage cactus clones and to determine how environmental conditions and crop growth affect evapotranspiration. The study was conducted in the municipality of Serra Talhada, in the state of Pernambuco, Brazil. Crop growth was monitored through changes in the cladode area index (CAI) and through the soil cover fraction, calculated at the end of the cycle. Real evapotranspiration (ET) of the three evaluated clones was obtained as the residual term in the soil water balance method. No difference was observed between soil water balance components, even though the evaluated clones were of different genus and had different CAI increments. Accumulated ET was of $1,173 \mathrm{~mm}$ during the 499 days of the experiment, resulting in daily average of $2.35 \mathrm{~mm}$. The CAI increases the water consumption of the Orelha de Elefante Mexicana clone. In dry conditions, the water consumption of the Miúda clone responds more slowly to variation in soil water availability. The lower evolution of the CAI of the IPA Sertânia clone, during the rainy season, leads to a higher contribution of the evaporation component in ET. The atmospheric demand controls the ET of clones only when there is higher soil water availability; in this condition, the water consumption of the Miúda clone decreases more rapidly with the increase of atmospheric demand.
\end{abstract}

Index terms: Nopalea, Opuntia, CAM photosynthetic pathway, evapotranspiration.

\section{Dinâmica de água no solo e evapotranspiração de clones de palma forrageira sob condições de sequeiro}

\begin{abstract}
Resumo - O objetivo deste trabalho foi avaliar a dinâmica de água no solo em áreas cultivadas com clones de palma forrageira, e determinar como as condições ambientais e o crescimento da cultura afetam a evapotranspiração. O estudo foi conduzido no Município de Serra Talhada, no Estado de Pernambuco. $\mathrm{O}$ crescimento da cultura foi monitorado por meio da evolução do índice de área do cladódio (IAC) e da fração de cobertura do solo calculada ao final do ciclo. A evapotranspiração real (ET) dos três clones avaliados foi obtida como resíduo do método do balanço hídrico do solo. Não foi observada diferença entre os componentes do balanço hídrico do solo, embora os clones pertencessem a gêneros diferentes e apresentassem diferentes incrementos do IAC. A ET acumulada foi de $1.173 \mathrm{~mm}$ durante os 499 dias experimentais, com média diária de 2,35 mm. O IAC aumenta o consumo de água do clone Orelha de Elefante Mexicana. Em condições de seca, o consumo de água do clone Miúda responde mais lentamente à variação no armazenamento de água no solo. A menor evolução do IAC do clone IPA Sertânia, durante o período chuvoso, induz à maior contribuição do componente de evaporação na ET. A demanda atmosférica controla a ET dos clones apenas quando há maior disponibilidade de água no solo; nesta condição, o consumo de água do clone Miúda diminui mais rapidamente com o aumento da demanda atmosférica.
\end{abstract}

Termos para indexação: Nopalea, Opuntia, via fotossintética MAC, evapotranspiração.

\section{Introduction}

The Brazilian semiarid region is characterized by high temporal and spatial rainfall variability and high atmospheric evaporation, which, combined, result in a severe soil water deficit over several periods of the year (>1,000 $\mathrm{mm}$ per year) (Moura et al., 2007). In order to meet the fodder demand of animals, especially during 
droughts, the use of plant species that are more adapted to local conditions is common among producers. Forage cactus is a native species of Mexico, with the Crassulacean acid metabolism (CAM) photosynthetic pathway and great potential for use in semiarid regions of Northeast Brazil, besides being one of the most important cacti worldwide (Oliveira et al., 2010).

Despite the importance of forage cactus, there is little information about this crop's interaction with the environment, in particular with regard to soil water dynamics and evapotranspiration (ET). Soil water dynamics provides essential knowledge for agricultural management practices during different phenological stages for crop yield improvement (Zougmoré et al., 2004; Ghiberto et al., 2011), whereas ET provides important information for water management both in irrigated and dry soil conditions. However, records on ET data for forage cactus are few around the world and practically non-existent in the Brazilian semiarid region, where this crop is of great economic importance (Oliveira et al., 2010).

Previous studies have used the soil water balance method to quantify the evapotranspiration of the Opuntia ellisiana Griffiths cactus in the semiarid region of Kingsville, Texas, USA (Han \& Felker, 1997). The micrometeorological method of turbulent vortices has also been adopted to determine energy fluxes, ET, and crop coefficient for cactus pear [Opuntia ficus-indica (L.) Mill.] cultivated for fruit production in Sicily, Italy (Consoli et al., 2013).

Soil water availability is one of the main factors affecting plant growth. Consequently, plant cover influences soil water moisture and the evapotranspiration process. Studies carried out on CAM photosynthetic pathway in others regions of the world have shown that atmospheric demand governs cactus aerodynamic conductance and that crop growth affects energy partition, influencing crop evapotranspiration (San José et al. 2007a, 2007b; Consoli et al., 2013). However, this type of study has not been developed for cactus species in the semiarid region of Brazil.

The objective of this work was to evaluate soil water dynamics in areas cultivated with forage cactus clones and to determine how environmental conditions and crop growth affect evapotranspiration.

\section{Materials and Methods}

The study was conducted in the municipality of Serra Talhada, in the state of Pernambuco, Brazil
( $7^{\circ} 58^{\prime} \mathrm{S}, 42^{\circ} 50^{\prime} \mathrm{W}$, at $461 \mathrm{~m}$ above sea level). Rainfall in the region is around $642.1 \mathrm{~mm}$ per year, occurring mainly between January and April. Annual mean temperature is about $24.8^{\circ} \mathrm{C}$, and relative humidity is approximately $62.5 \%$, resulting in an atmospheric evaporative demand of around $1,800 \mathrm{~mm}$ per year and in a deficit of 1,143 $\mathrm{mm}$ per year, according to the climatological water balance proposed by Thornthwaite \& Matter (1955), assuming 100-mm available water capacity. The soil of the experimental area is a Argissolo Vermelho-Amarelo eutrófico franco arenoso (Santos et al., 2006) (sandy loam Yellow-Red Eutrophic Acrisol); soil physical characteristics are shown in Table 1.

The experimental area was established in February 2010 and was planted with three forage cactus clones: IPA-200205-IPA-Sertânia [Nopalea cochenillifera (L.) Salm-Dyck], IPA-100004-Miúda [Nopalea cochenillifera (L.) Salm-Dyck], and IPA-200016-Orelha de Elefante Mexicana [Opuntia stricta (Haw.) Haw.], at 1.6x0.2-m spacing in contour lines, with plant density of 31,250 plants per hectare. The area was subdivided into nine experimental plots, containing four rows, each with 20 plants, occupying $25.6 \mathrm{~m}^{2}$. The floor area was $10.24 \mathrm{~m}^{2}$, with 32 useful plants distributed in a randomized complete block design with three replicates. Treatments consisted of the three evaluated clones. During the experimental period, $130 \mathrm{~kg} \mathrm{ha}^{-1} \mathrm{~N}$ fertilizer were applied at three dates. Chemicals, such as herbicides and insecticides, were used when necessary. The productive cycle occurred between February 2010 and March 2012 under nonirrigated conditions.

The weather conditions during the experiment were monitored by an automatic weather station located approximately $700 \mathrm{~m}$ from the study area, belonging to the Brazilian National Institute of Meteorology (Instituto Nacional de Meteorologia, 2015). Reference evapotranspiration $\left(\mathrm{ET}_{\mathrm{o}}\right)$ was estimated using the data obtained by the FAO-56 Penman-Monteith method (Allen et al., 1998).

Soil water content was monitored using a portable capacitance probe Diviner 2000 model (Sentek Technologies, Stepney, Adelaide, Australia) and nine fixed access tubes installed more than $0.90 \mathrm{~m}$ deep in the soil; one in each experimental plot. The readings were taken up to $0.70 \mathrm{~m}$-depth, after the crop root system has not exceeded the depth of $0.60 \mathrm{~m}$, and 
observations were made on 1-m deep trenches. The probe was initially calibrated after the installation of the tubes in the experimental plots, as recommended by the manufacturer. Soil water content was measured every $0.10 \mathrm{~m}$ at 3 -day intervals. Moisture monitoring started on October $20^{\text {th }}, 2010$, and ended on March $2^{\text {nd }}$, 2012.

Soil water balance components were quantified for a 0.60-m depth layer, using the following expression (Libardi, 2005): $\mathrm{P}-\mathrm{ET} \pm \mathrm{Q}-\mathrm{R}=\Delta \mathrm{A}$, in which: $\mathrm{P}$ is the rainfall in millimeters; ET is the evapotranspiration in millimeters; Q is the soil water flow; the negative and positive signs represent deep drainage or capillary rise, respectively, both in millimeters; $\mathrm{R}$ is the runoff in millimeters; and $\Delta \mathrm{A}$ is the soil water storage variation, also in millimeters.

Rainfall was monitored using the rain gauge from the automatic weather station of the Brazilian National Institute of Meteorology. Based on data from the layers below $(0.50 \mathrm{~m})$ and above $(0.70 \mathrm{~m})$, deep drainage and capillary rise were determined using the Buckingham-Darcy equation (Libardi, 2005), according to the lower limit of the soil profile (0.60-m depth), by: $\mathrm{Q}=-\mathrm{K}(\theta) \Delta \psi \mathrm{t} / \Delta \mathrm{z}$, in which: $\mathrm{Q}$ is the soil water flow by deep drainage (negative sign) or by capillary rise (positive sign) in millimeters per day; $K(\theta)$ is the unsaturated soil hydraulic conductivity in millimeters per day, obtained by the $\mathrm{K}(\theta)=\mathrm{K}_{\mathrm{o}} \cdot \exp \left[\gamma\left(\theta-\theta_{\mathrm{o}}\right)\right]$ ratio, in which $\mathrm{K}_{\mathrm{o}}$ is the saturated soil hydraulic conductivity ( $\mathrm{mm}$ per day), $\gamma$ is the parameter adjusted from the equation, and $\theta-\theta_{\mathrm{o}}$ is the difference between actual soil moisture and saturated soil moisture; and $\Delta \psi t / \Delta$ zis the soil total water potential gradient between the 0.50 and 0.70 -m layers.
The $\psi t$ parameter was estimated for both depths by the equation below: $\psi \mathrm{t}=\alpha \mathrm{e}^{-\beta \theta}$, in which $\alpha$ and $\beta$ are dimensionless parameters.

The $\mathrm{K}(\theta)$ and $\psi t$ equation parameters were adjusted through tensiometers and soil moisture measurements at eight depths, which were obtained over time for soil water redistribution, through an instantaneous profile method.

Runoff (R) was estimated by the curve number method proposed by Mockus (1972), which was developed for large volumes of rain - considering soil-vegetation complex, soil type, soil use, initial soil moisture, and hydrological properties of the site - and is represented by the following expression:

$$
\mathrm{R}=\left(\mathrm{P}-0.2\left(\frac{25,400}{\mathrm{CN}}-254\right)\right)^{2} / \mathrm{P}+0.8\left(\frac{25,400}{\mathrm{CN}}-254\right)
$$

in which: $\mathrm{P}$ is the rainfall in millimeters for the analyzed period; and $\mathrm{CN}$ is the curve number, adopted for the study, equal to 75, which represents moderate infiltration rate, when the soil is completely wet.

Soil water storage was determined by the integration of the water depth values for each $0.10 \mathrm{~m}$, which were obtained by the Diviner 2000 capacitance probe (Sentek Technologies, Stepney, Adelaide, Australia). Water storage variation $(\Delta \mathrm{A})$ in the soil profile at $0.60-\mathrm{m}$ depth was determined by the difference between each initial and final value of the evaluated period.

Accumulated actual evapotranspiration $\left(\mathrm{ET}_{\mathrm{ac}}\right)$ during the studied period and daily mean evapotranspiration $\left(\mathrm{ET}_{\mathrm{d}}\right)$ of the different clones evaluated were obtained as the residual term in the soil water balance equation. The ratio between the actual

Table 1. Physical characteristics of the soil cultivated with the evaluated forage cactus clones under rainfed conditions in the Brazilian semiarid region.

\begin{tabular}{|c|c|c|c|c|c|c|}
\hline Depth & Soil apparent density & Soil particle density & \multirow{2}{*}{$\begin{array}{c}\text { Total porosity } \\
(\%)\end{array}$} & Sand & Silt & Clay \\
\hline$(\mathrm{m})$ & ------------------------------(1 & --------------------------- & & -------- & $-\left(\mathrm{g} \mathrm{kg}^{-1}\right)$ & ------- \\
\hline $0.0-0.10$ & 1.54 & 2.52 & 38.93 & 727.18 & 227.20 & 45.63 \\
\hline $0.10-0.20$ & 1.58 & 2.55 & 37.95 & 712.73 & 241.55 & 45.80 \\
\hline $0.20-0.30$ & 1.56 & 2.58 & 39.30 & 708.18 & 251.43 & 40.38 \\
\hline $0.30-0.40$ & 1.50 & 2.58 & 41.80 & 637.43 & 277.18 & 85.48 \\
\hline $0.40-0.50$ & 1.49 & 2.58 & 42.47 & 669.95 & 242.05 & 87.98 \\
\hline $0.50-0.60$ & 1.51 & 2.59 & 41.58 & 646.60 & 275.90 & 77.48 \\
\hline Average & 1.53 & 2.57 & 40.34 & 683.68 & 252.55 & 63.79 \\
\hline Standard deviation & 0.03 & 0.02 & 1.61 & 32.35 & 15.99 & 19.86 \\
\hline CV $(\%)$ & 1.96 & 0.82 & 4.00 & 4.73 & 6.33 & 31.12 \\
\hline
\end{tabular}


and reference evapotranspiration $\left(\mathrm{ET} / \mathrm{ET}_{\mathrm{o}}\right)$ was also obtained. Throughout the conversion, the negative values of ET, runoff, and deep drainage represent soil water output; the positive signals of capillary rise indicate soil water input; and the positive or negative signals represent $\Delta \mathrm{A}$.

Water balance components in the soil and the ET/ $\mathrm{ET}_{\mathrm{o}}$ ratio were determined for 37 periods, with mean intervals of 14 days. However, to simplify the data amount, these periods were combined into nine, lasting between 49 and 68 days each: period 1, from October $20^{\text {th }}, 2010$, to December $15^{\text {th }}, 2010$; period 2, from December $16^{\text {th }}, 2010$, to February $9^{\text {th }}, 2011$; period 3, from February $10^{\text {th }}, 2011$, to April $18^{\text {th }}, 2011$; period 4, from April $19^{\text {th }}, 2011$, to June $17^{\text {th }}, 2011$; period 5, from June $18^{\text {th }}, 2011$, to August $8^{\text {th }}, 2011$; period 6, from August $9^{\text {th }}, 2011$, to September 26 ${ }^{\text {th }}, 2011$; period 7, from September $27^{\text {th }}, 2011$, to November $14^{\text {th }}, 2011$; period 8 , from November $15^{\text {th }}, 2011$, to January $4^{\text {th }}$, 2012; and period 9, from January $5^{\text {th }}, 2012$, to March $2^{\text {nd }}, 2012$. These periods were divided according to crop-growth monitoring periods.

To obtain the increment of the CAI, the cladode number per plant (CNP) was determined, and cladode length and width were measured throughout the experimental period for three plants per replicate. Mathematical equations for each forage cactus clone were used for cladode area estimation (Silva et al., 2014), and the CAI was calculated according to Pinheiro et al. (2014). Mathematic models were adjusted to the CAI values depending on the days after cutting. Models were developed in order to obtain the daily and monthly CAI increments for the three evaluated clones.

At the end of the cycle, soil cover index (\%) for each clone was calculated through the following equation:

$$
I C=\frac{\pi^{L^{2}} / 4}{\pi^{E^{2}} / 4} \times 100,
$$

in which: $\mathrm{L}$ is the plant canopy mean in meters; and $\mathrm{E}$ is the spacing between crop rows $(1.6 \mathrm{~m})$.

In the statistical analysis, soil water balance component means, standard deviations, and coefficients of variation were obtained for the nine periods evaluated for each of the three clones. Assuming the adopted design, the comparison of data from $\mathrm{Q}, \Delta \mathrm{A}$, accumulated $\mathrm{ET}$, and daily ET was made by analysis of variance and, when significant,
Tukey's test, at 5\% probability, was applied. The linear relationship between actual evapotranspiration, reference evapotranspiration, increment of the CAI, and soil water storage variation was used to analyze how environmental conditions and crop growth affects evapotranspiration. The significance of the equations and their parameters was evaluated at 1,5 , and $10 \%$ probability.

\section{Results and Discussion}

The meteorological variables obtained for 2010 2012 were atypical. The local long-term mean annual rainfall is $642 \mathrm{~mm}$. In 2010 and 2011, the values were of 730 and $960 \mathrm{~mm}$, respectively. Furthermore, an evidently prolonged drought in 2012 was observed, resulting in an annual rainfall of $238 \mathrm{~mm}$, representing only $37 \%$ of the local long-term mean.

As a result, the curve number method revealed low runoff values for all analyzed periods, representing less than $1 \%$, i.e. $9.3 \mathrm{~mm}$, of total rainfall. Many studies on soil water dynamics consider this component as insignificant (Castellanos et al., 2013). However, it depends on soil type, soil texture, planting system, soil cover extent, land slope, soil water infiltration, and rain intensity (Zougmoré et al., 2004; Schwartz et al., 2010; Yadav et al., 2011).

Although the evaluated clones are of different genera (Nopalea ssp. and Opuntia ssp.) and have distinct growth habits, the cumulative values of the water balance components $\left(\mathrm{DD} / \mathrm{CR}, \Delta \mathrm{A}\right.$, and $\mathrm{ET}_{\mathrm{ac}}$ ) were similar per cycle (Table 2). However, differences between $\mathrm{DD} / \mathrm{CR}, \Delta \mathrm{A}$, and $\mathrm{ET}_{\mathrm{ac}}$ were verified for some periods over time, depending on rainfall regime (Table 3). In the experimental periods 1 to 3, from October $20^{\text {th }}, 2010$, to April $18^{\text {th }}, 2011$, increased rainfall was recorded, with subsequent reduction until period 8, from November $15^{\text {th }}, 2011$, to January $4^{\text {th }}, 2012$, when there was an increase until the end of the crop cycle. Throughout the analysis period, the accumulated rainfall was $1,269.1 \mathrm{~mm}$.

Deep drainage occurred especially in periods 3 and 4, from February $10^{\text {th }}, 2011$, to April $18^{\text {th }}, 2011$, and from April $19^{\text {th }}, 2011$, to June $17^{\text {th }}, 2011$, respectively. This stream type is more frequent in intense rainfall events, when the soil has a sandy texture, as reported by Gaiser et al. (2004). However, deep drainage can also be enhanced under prolonged drought conditions 
in areas cultivated with some Opuntia spp., as the root system can reach greater depths, forming channels in the soil that promote water movement, as found by Snyman (2006a).

Despite the high cumulative values of rainfall during some periods $(1,2$, and 9), drainage was low, because, after dry periods, most of the water is used in soil replenishment or is extracted by the plant root system, as described by Primo et al. (2015). This can be explained by the high capacity of cacti to store water in cladodes and by the elongation of the root

Table 2. Comparison of the cumulative values of deep drainage (DD), capillary rise (CR), soil water storage variation $(\triangle \mathrm{A})$, actual evapotranspiration $\left(\mathrm{ET}_{\mathrm{ac}}\right)$, and daily actual evapotrasnpiration $\left(\mathrm{ET}_{\mathrm{d}}\right)$ of the IPA Sertânia, Miúda, and Orelha de Elefante Mexicana (OEM) clones during the experimental period of 499 days $^{(1)}$.

\begin{tabular}{lcccc}
\hline Clone & $\mathrm{DD} / \mathrm{CR}$ & $\Delta \mathrm{A}$ & $\mathrm{ET}_{\mathrm{ac}}$ & $\begin{array}{c}\mathrm{ET}_{\mathrm{d}} \\
(----------(\mathrm{mm})\end{array}$ \\
\hline IPA Sertânia & $-272.2 \mathrm{a}$ & $30.0 \mathrm{a}$ & $-1,047.3 \mathrm{a}$ & $-2.11 \mathrm{a}$ \\
Miúda & $-53.1 \mathrm{a}$ & $47.4 \mathrm{a}$ & $-1,248.9 \mathrm{a}$ & $-2.50 \mathrm{a}$ \\
OEM & $-94.3 \mathrm{a}$ & $41.2 \mathrm{a}$ & $-1,214.2 \mathrm{a}$ & $-2.43 \mathrm{a}$ \\
\hline Average & -139.9 & 39.5 & $-1,173.3$ & -2.35 \\
Standard deviation & 116.4 & 8.8 & 107.8 & 0.20 \\
CV $(\%)$ & 83.2 & 22.4 & 9.2 & 9.0 \\
\hline
\end{tabular}

(1)Means followed by equal letters, in the columns, do not differ by Tukey's studentized test, at $5 \%$ probability. system, which increases rapidly after being subjected to long periods of drought (Snyman, 2006a, 2006b). These roots, called "rain roots", are extensive, dense, and close to the soil surface. They appear shortly after the soil is moistened, quickly absorbing water, and disappear soon after when the soil dries up (Snyman, 2006b).

$\Delta \mathrm{A}$ showed positive values especially in periods that followed major droughts, such as period 1, from October $20^{\text {th }}, 2010$, to December $15^{\text {th }}, 2010$. In periods 2 and 3 , from December $16^{\text {th }}, 2010$, to February $9^{\text {th }}, 2011$, and from February $10^{\text {th }}, 2011$, to April $18^{\text {th }}$, 2011 , respectively, the $\Delta \mathrm{A}$ values were also positive, although with smaller magnitudes than in period 1 and with increasing water extraction by plants. In period 9, from January $5^{\text {th }}, 2012$, to March $2^{\text {nd }}, 2012$, which also occurred after a long period with low rainfall, the variation was also positive. However, changes in stored water were lower than those found during period 1, since rainfall was higher at the end of 2011 than at the end of 2010 . Some $\Delta \mathrm{A}$ positive values were still observed in periods 5 and 7, from June $18^{\text {th }}, 2011$, to August $8^{\text {th }}, 2011$, and from September $27^{\text {th }}, 2011$, to November $14^{\text {th }}, 2011$, respectively, even with lower rainfall levels, which may be related to the reduction of plant water consumption and the occurrence of rainfall events at the end of the period. $\Delta \mathrm{A}$ negative values are probably a result of increased root activity after periods with higher rainfall, such as: period 4,

Table 3. Rainfall (P), number of days per period (DNP), reference evapotranspiration (ET $\mathrm{ET}_{\mathrm{o}}$, runoff (R), deep drainage (DD), capillary rise $(\mathrm{CR})$, soil water storage variation $(\triangle \mathrm{A})$, and accumulated actual evapotranspiration (ET $\mathrm{Tac}_{\mathrm{ac}}$ of the IPA Sertânia (IPA), Miúda (MIU), and Orelha de Elefante Mexicana (OEM) clones.

\begin{tabular}{|c|c|c|c|c|c|c|c|c|c|c|c|c|c|}
\hline \multirow[t]{3}{*}{ Period $^{(1)}$} & \multirow[t]{3}{*}{ DNP } & \multirow[t]{2}{*}{$\mathrm{P}$} & \multirow[t]{2}{*}{$\mathrm{ET}_{\mathrm{o}}$} & \multirow[t]{2}{*}{$\mathrm{R}$} & \multicolumn{3}{|c|}{$\mathrm{DD} / \mathrm{CR}$} & \multicolumn{3}{|c|}{$\Delta \mathrm{A}$} & \multicolumn{3}{|c|}{$\mathrm{ET}_{\mathrm{ac}}$} \\
\hline & & & & & IPA & MIU & OEM & IPA & MIU & OEM & IPA & MIU & OEM \\
\hline & & & & & & & & $-(\mathrm{mm})-$ & & & & & \\
\hline 1 & 56 & 176.0 & 301.6 & -1.4 & $-3.5 \mathrm{a}$ & $-1.1 \mathrm{a}$ & $-1.7 \mathrm{a}$ & $76.7 \mathrm{a}$ & $66.8 \mathrm{ab}$ & $59.4 \mathrm{~b}$ & $-104.3 a$ & $-96.9 a$ & $-113.5 a$ \\
\hline 2 & 56 & 230.9 & 273.1 & -1.7 & $-17.1 \mathrm{a}$ & $-3.3 \mathrm{a}$ & $-6.9 \mathrm{a}$ & $0.9 \mathrm{a}$ & $0.7 \mathrm{a}$ & $2.6 \mathrm{a}$ & $-211.5 \mathrm{a}$ & $-225.0 \mathrm{a}$ & $-219.8 \mathrm{a}$ \\
\hline 3 & 68 & 439.4 & 311.9 & -2.8 & $-117.5 b$ & $-29.0 \mathrm{a}$ & $-39.4 a$ & $26.8 \mathrm{a}$ & $23.4 \mathrm{a}$ & $24.3 \mathrm{a}$ & $-295.7 b$ & $-380.8 \mathrm{a}$ & $-373.0 \mathrm{a}$ \\
\hline 4 & 60 & 133.9 & 216.9 & -1.0 & $-80.7 b$ & $-12.4 \mathrm{a}$ & $-26.9 a$ & $-34.6 a$ & $-26.3 a$ & $-32.3 a$ & $-104.2 b$ & $-180.7 \mathrm{a}$ & $-163.9 \mathrm{a}$ \\
\hline 5 & 52 & 55.2 & 201.8 & -0.5 & $-37.0 \mathrm{a}$ & $-3.1 \mathrm{a}$ & $-10.0 \mathrm{a}$ & $9.1 \mathrm{a}$ & $4.3 \mathrm{a}$ & $5.5 \mathrm{a}$ & $-37.5 a$ & $-66.6 a$ & $-63.4 a$ \\
\hline 6 & 49 & 20.3 & 252.0 & -0.2 & $-10.5 \mathrm{a}$ & $-2.9 \mathrm{a}$ & $-5.7 \mathrm{a}$ & $-37.8 b$ & $-30.0 \mathrm{ab}$ & $-26.8 \mathrm{a}$ & $-39.7 a$ & $-55.1 \mathrm{a}$ & $-41.2 \mathrm{a}$ \\
\hline 7 & 49 & 69.7 & 275.8 & -0.8 & $-3.6 a$ & $-0.4 \mathrm{a}$ & $-1.0 \mathrm{a}$ & $5.2 \mathrm{a}$ & $5.4 \mathrm{a}$ & $7.7 \mathrm{a}$ & $-67.7 \mathrm{a}$ & $-71.1 \mathrm{a}$ & $-68.1 \mathrm{a}$ \\
\hline 8 & 51 & 11.2 & 311.2 & -0.1 & $-0.8 \mathrm{a}$ & $-0.1 \mathrm{a}$ & $-0.7 \mathrm{a}$ & $-31.8 \mathrm{a}$ & $-29.5 a$ & $-27.3 a$ & $-39.8 a$ & $-42.8 \mathrm{a}$ & $-37.8 \mathrm{a}$ \\
\hline 9 & 58 & 132.5 & 331.9 & -1.0 & $-1.5 \mathrm{a}$ & $-0.8 \mathrm{a}$ & $-2.1 \mathrm{a}$ & $32.9 \mathrm{a}$ & $15.2 \mathrm{~b}$ & $28.1 \mathrm{a}$ & $-146.9 \mathrm{a}$ & $-129.9 \mathrm{a}$ & $-133.5 \mathrm{a}$ \\
\hline
\end{tabular}

(1) Period 1, from October $20^{\text {th }}, 2010$, to December $15^{\text {th }}, 2010$; period 2, from December $16^{\text {th }}, 2010$, to February $9^{\text {th }}, 2011$; period 3, from February $10^{\text {th }}$, 2011,

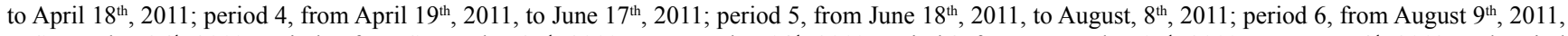
to September $26^{\text {th }}, 2011$; period 7 , from September $27^{\text {th }}, 2011$, to November $14^{\text {th }}, 2011$; period 8 , from November $15^{\text {th }}$, 2011, to January $4^{\text {th }}, 2012$; and period 9 , from January $5^{\text {th }}, 2012$, to March $2^{\text {nd }}, 2012$. Equal letters, in the columns, representing the same component of soil water balance, do not differ by Tukey's studentized test, at $5 \%$ probability. The values of $\mathrm{DP} / \mathrm{CR}, \triangle \mathrm{A}$, and $\mathrm{ET}_{\mathrm{ac}}$ are averages of three replicates. 
from April $19^{\text {th }}, 2011$, to June $17^{\text {th }}, 2011$; period 6 , from August $9^{\text {th }}, 2011$, to September $26^{\text {th }}, 2011$; and period 8 , from November $15^{\text {th }}, 2011$, to January $4^{\text {th }}$, 2012. Subsequently, water extraction by roots was recorded, increasing cladode mass (Snyman, 2006a, 2006b).

$\Delta \mathrm{A}$ positive values were significantly higher in areas cultivated with the IPA Sertânia and Miúda clones during periods 1 and 9, after a long drought. In turn, more negative values were recorded in period 6 , when less rainfall was observed (Table 3 ).

In terms of $\mathrm{ET}_{\mathrm{d}}$ (Figure 1), differences between clones were found only in periods 3 and 4, which had the highest rainfall. In these periods, the Miúda and Orelha de Elefante Mexicana clones had the highest ET values when compared with IPA Sertânia. This result is associated to the highest deep drainage, which occurred in periods 3 and 4 .

Therefore, the $\mathrm{ET}_{\mathrm{ac}}$ and $\mathrm{ET}_{\mathrm{d}}$ values for forage cactus during the 499 days of the experiment were of 1,170 and $2.35 \mathrm{~mm}$ per day, respectively. Lower values were reported by Han \& Felker (1997) in the semiarid region of Kingsville, Texas, USA, with climatic conditions similar to those of present study. The authors obtained mean values of $1.53 \mathrm{~mm}$ per day for $O$. ellisiana in the third production year during a period with $883 \mathrm{~mm}$ of rainfall. However, during the fourth production year, with $662 \mathrm{~mm}$ of rain, the actual evapotranspiration rate was $1.37 \mathrm{~mm}$ per day. In terms of accumulated evapotranspiration, values around 559 and $499 \mathrm{~mm}$ were registered in the third and fourth cycles, respectively.

The values obtained in the present study are closer to the mean daily rates of $2.5 \mathrm{~mm}$ reported by Consoli et al. (2013), when the atmospheric demand was in the order of $5.0 \mathrm{~mm}$ per day and when the accumulated actual evapotranspiration was $1,329 \mathrm{~mm}$. These results confirm that the evapotranspiration rates of CAM species are lower than those of $\mathrm{C}_{3}$ and $\mathrm{C}_{4}$ plants due to $\mathrm{CO}_{2}$ assimilation priority during the night, when atmospheric demand is low (Cushman, 2001). Studies conducted in the Brazilian semiarid conditions showed evapotranspiration rates ranging from 1.2 to $7.5 \mathrm{~mm}$ per day. Silva et al. (2012) found mean of $4.7 \mathrm{~mm}$ per day for $\mathrm{C}_{4}$ sugarcane plant (Saccharum spp.) during the irrigated ratoon cycle. However, Lima et al. (2011), while studying $\mathrm{C}_{3}$ cowpea plant (Vigna unguiculata $\mathrm{L}$.) under rainfed conditions in the state of Paraiba, Brazil, found evapotranspiration mean of $3.8 \mathrm{~mm}$ per day; however, the values varied from 1.0 to $6.0 \mathrm{~mm}$ per day.

Despite that, ET daily mean rates for forage cactus clones were low $(<2.5 \mathrm{~mm})$ during the present experiment. Values ranged between 0.71 and $4.22 \mathrm{~mm}$ per day for IPA Sertânia; 0.86 and $5.42 \mathrm{~mm}$ per day for Miúda; and 0.74 and $5.29 \mathrm{~mm}$ per day for Orelha de Elefante Mexicana (Figure 1). Consoli et al. (2013) recorded values up to $4.2 \mathrm{~mm}$ per day for cactus pear. For other CAM species, such as pineapple [Ananas comosus (L.) Merr.], Azevedo et al. (2007) reported mean values of $4.1 \mathrm{~mm}$ per day, reaching up to $4.6 \mathrm{~mm}$ per day in the second vegetative growth stage. It is known that some CAM species adjust their standard $\mathrm{CO}_{2}$ capture in $\mathrm{C}_{3}$ plants when subjected to higher water availability conditions (Taiz \& Zeiger, 2009). However, young cladodes and flower buds open the

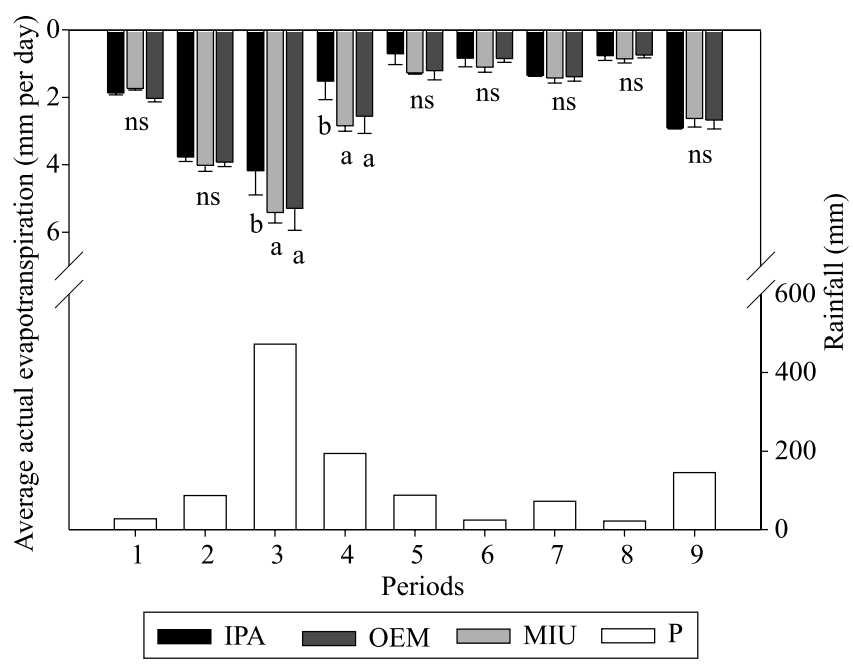

Figure 1. Mean daily evapotranspiration of the evaluated forage cactus clones and accumulated rainfall $(\mathrm{P})$ of the experimental period of 499 days divided into nine periods. Period 1, from October 20 ${ }^{\text {th }}, 2010$, to December $15^{\text {th }}, 2010$; period 2, from December $16^{\text {th }}, 2010$, to February $9^{\text {th }}, 2011$; period 3, from February $10^{\text {th }}, 2011$, to April $18^{\text {th }}, 2011$; period 4, from April 19 ${ }^{\text {th }}, 2011$, to June $17^{\text {th }}$, 2011; period 5 , from June $18^{\text {th }}, 2011$, to August $8^{\text {th }}, 2011$; period 6 , from August $9^{\text {th }}, 2011$, to September 26 $6^{\text {th }}, 2011$; period 7, from September $27^{\text {th }}, 2011$, to November $14^{\text {th }}, 2011$; period 8 , from November $15^{\text {th }}, 2011$, to January $4^{\text {th }}, 2012$; and period 9, from January $5^{\text {th }}, 2012$, to March $2^{\text {nd }}, 2012$. Equal letters in vertical bars do not differ by Tukey's studentized test, at

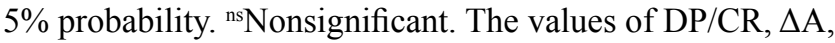
and $\mathrm{ET}_{\mathrm{ac}}$ are averages of three replicates. IPA, IPA Sertânia; MIU, Miúda; and OEM, Orelha de Elefante Mexicana. 
stomata during the day, whereas adult cladodes open them during the night, as described by Acevedo et al. (1983). Therefore, as observed in the present study, in high soil water availability periods, it is expected that the ET of forage cactus will reach its highest values, near those found in the environment for $\mathrm{C}_{3}$ and $\mathrm{C}_{4}$ plants. However, this result is associated with the soil water evaporation component (Han \& Felker, 1997).

The highest daily ET rates were observed for periods 2,3 , and 4 , which were mostly rainy days. ET rise occurred in period 7, when it increased with higher rainfall levels (Figure 1). In period 8, there was a new reduction at the end of the cycle, followed by a further increase due to new rainfall events. In periods 4 and 9 , in which the total rainfall did not exceed accumulated ET, forage cactus continued to show ET values above average, which is possibly related to its ability to extract soil water and water stored in the cladode. Between periods 5 and 8, rainfall reduction was also followed by a decrease in ET rates. In low soil water availability conditions, the apical meristem of cactus pear roots dies while the deeper cells continue to divide and increase their length, but at lower rates (Dubrovsky et al., 1998). In addition, forage cactus water loss occurs preferably by parenchyma, allowing higher collenchyma hydration and ensuring continuous productive increment (Goldstein et al., 1991).

The ET/ET $\mathrm{E}_{0}$ is indicative of crop evapotranspiration response to atmospheric demand. High values were verified for the wettest periods, especially for the Miúda and Orelha de Elefante Mexicana clones during period 3, when the atmospheric evaporative demand decreased, resulting in ET/ET $>1$ (Figure 2). This result is related to air vapor deficit reduction, which increased nocturnal transpiration by the cacti (Acevedo et al., 1983).

The lowest values were obtained in periods 5 to 9 due to the lower rain events and increased atmospheric evaporative demand. Furthermore, the ET/ET values of the clones, in low soil water availability conditions, are very similar. On average, the $\mathrm{ET} / \mathrm{ET}_{\mathrm{o}}$ values of the IPA Sertânia, Miúda, and Orelha de Elefante Mexicana clones were around $0.41 \pm 0.22,0.50 \pm 0.30$, and $0.49 \pm 0.29$, respectively, and the mean for the three clones was equal to $0.47 \pm 0.05$. Consoli et al. (2013) reported relative $\mathrm{ET} / \mathrm{ET}_{0}$ mean values of 0.40 for forage cactus and between 0.25 and 0.50 for cactus pear. Silva et al. (2012) found $E T / E T_{0}$ values ranging from 0.65 to 1.15 for irrigated sugar cane grown in the Brazilian semiarid region. For cowpea, this ratio ranged between 0.83 and 0.99 , depending on the phenological phase (Lima et al., 2011). Azevedo et al. (2007) studied pineapple, another CAM, whose ET/ETo was 0.88 , slightly changing over its cycle.

Shortly after the wettest periods, the increase in the CAI was superior for the Orelha de Elefante Mexicana clone, whereas a progressive increase was observed for Miúda until period 7, when its evolution rate slightly decreased (Figure 3). In turn, IPA Sertânia showed higher increase rates for the CAI at the end of the analyzed period. Although the CAI is larger for the Orelha de Elefante Mexicana clone, ET rates were not higher when compared to those of the other two clones. At the end of the studied period, the soil cover index for the Orelha de Elefante Mexicana clone was

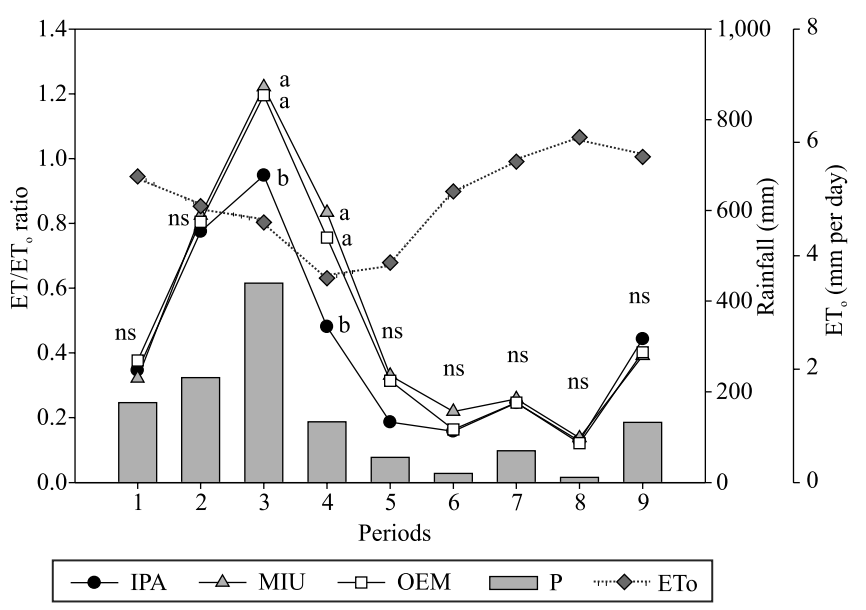

Figure 2. ET/ETo ratio for the three evaluated forage cactus clones, rainfall $(\mathrm{P})$, and reference evapotranspiration (ETo) during the experimental period of 499 days divided into nine periods. Period 1 , from October $20^{\text {th }}, 2010$, to December $15^{\text {th }}$, 2010; period 2, from December $16^{\text {th }}, 2010$, to February $9^{\text {th }}$, 2011; period 3, from February $10^{\text {th }}, 2011$, to April $18^{\text {th }}, 2011$; period 4, from April 19 $9^{\text {th }}, 2011$, to June $17^{\text {th }}$, 2011; period 5 , from June $18^{\text {th }}, 2011$, to August $8^{\text {th }}, 2011$; period 6 , from August $9^{\text {th }}, 2011$, to September $26^{\text {th }}, 2011$; period 7, from September $27^{\text {th }}, 2011$, to November $14^{\text {th }}, 2011$; period 8 , from November $15^{\text {th }}, 2011$, to January $4^{\text {th }}, 2012$; and period 9, from January $5^{\text {th }}, 2012$, to March $2^{\text {nd }}, 2012$. Equal letters in vertical bars do not differ by Tukey's studentized test, at $5 \%$ probability. ${ }^{n}$ Nonsignificant. The values of $\mathrm{DP} / \mathrm{CR}, \Delta \mathrm{A}$, and ETac are averages of three replicates. IPA, IPA Sertânia; MIU, Miúda; and OEM, Orelha de Elefante Mexicana. 
of $32 \pm 4 \%$, higher than that of IPA Sertânia, which was equal to $24 \pm 3 \%$, and of Miúda, to $22 \pm 3 \%$, both species of the genera Nopalea. The increases in the CAI and soil cover level during periods 3 and 4 may have contributed to higher ET rates.

The dashed line in the relationship between ET and $\mathrm{ET}_{\mathrm{o}}$ indicates that, under lower soil water availability conditions, $\mathrm{ET}_{\mathrm{o}}$ had little influence (Figure $4 \mathrm{~A}, \mathrm{D}$, and $G)$. However, under higher soil water availability conditions (continuous lines), ET values decreased with increased $\mathrm{ET}_{0}$, showing some control on transpiration. This tendency is similar between the three clones; however, the control on transpiration was clearly evident for Orelha de Elefante Mexicana $\left(R^{2}=0.69\right.$, angular coefficient $=-2.67)$ and IPA Sertânia $\left(R^{2}=0.70\right.$, angular coefficient $=-2.00$ ), although lower for Miúda

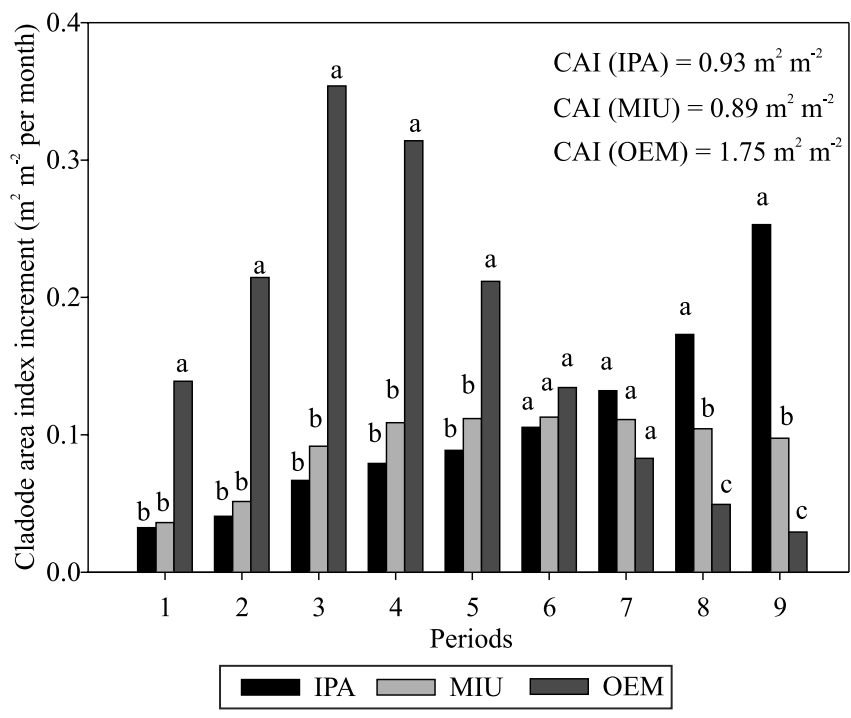

Figure 3. Cladode area index increment and values at the end of the cycle of the three evaluated forage cactus clones during the experimental period of 499 days divided into nine periods. Period 1 , from October $20^{\text {th }}, 2010$, to December $15^{\text {th }}$, 2010; period 2, from December $16^{\text {th }}, 2010$, to February $9^{\text {th }}$, 2011; period 3, from February $10^{\text {th }}, 2011$, to April $18^{\text {th }}, 2011$;

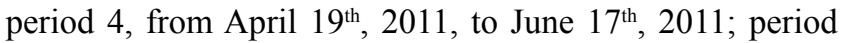
5 , from June $18^{\text {th }}, 2011$, to August $8^{\text {th }}, 2011$; period 6 , from August $9^{\text {th }}$, 2011, to September 26 ${ }^{\text {th }}, 2011$; period 7, from September $27^{\text {th }}, 2011$, to November $14^{\text {th }}, 2011$; period 8, from November $15^{\text {th }}, 2011$, to January $4^{\text {th }}, 2012$; and period 9, from January $5^{\text {th }}, 2012$, to March $2^{\text {nd }}, 2012$. Equal letters in vertical bars do not differ by Tukey's studentized test, at $5 \%$ probability. ${ }^{n}$ Nonsignificant. The values of $\mathrm{DP} / \mathrm{CR}, \Delta \mathrm{A}$, and $\mathrm{ET}_{\mathrm{ac}}$ are averages of three replicates. IPA, IPA Sertânia; MIU, Miúda; and OEM, Orelha de Elefante Mexicana.
$\left(\mathrm{R}^{2}=0.80\right.$, angular coefficient $\left.=-2.73\right)$, indicating that this last clone responds rapidly to variations in the environment, in a proportion of $2.73 \mathrm{~mm}$ of ET for $1.0 \mathrm{~mm}$ of $\mathrm{ET}_{\mathrm{o}}$, i.e. a 1.0-mm increment of atmospheric demand promotes actual evapotranspiration reduction in $2.73 \mathrm{~mm}$. This result can be associated with specific foliar area and increase of stomata number per unit cladode area in the Miúda clone. The smallest cladode area of this clone increases the interaction with the environment. The cladode area of the Orelha de Elefante Mexicana and IPA Sertânia clones is larger than that of the Miúda clone (Silva et al., 2014); therefore, its interaction is lower.

The ET rate of the Orelha de Elefante Mexicana clone was affected by the increase in the $\Delta \mathrm{CAI}$, with an ET rate of $0.87 \mathrm{~mm}$ for each $0.1 \mathrm{~m}^{2} \mathrm{~m}^{-2}$ increment per month (Figure $4 \mathrm{H}$ ). This clone presents greater cladode area (Silva et al., 2014); therefore, the development of the CAI promotes ET increase. The other two clones were not affected by $\Delta \mathrm{CAI}$ (Figure $4 \mathrm{~B}$ and $\mathrm{E}$ ).

The lowest ET values occurred (dashed line in Figures $4 \mathrm{C}, \mathrm{F}$, and I) especially when $\Delta \mathrm{A}$ was negative in periods 5, 6, 7, and 8. However, low ET was also observed when $\Delta \mathrm{A}$ was positive in period 1 , but atmospheric demand was lower. ET rate as function of $\Delta \mathrm{A}$ for the Miúda clone was lower (angular coefficient $=0.009$ ) than for IPA Sertânia (angular coefficient $=$ 0.012) and Orelha de Elefante Mexicana (angular coefficient $=0.015$ ). This indicates slower water consumption with soil water storage variation, i.e., $0.009 \mathrm{~mm}$ of evapotranspiration for each $1.0 \mathrm{~mm}$ of $\Delta \mathrm{A}$. This result can be indicative of the lower plasticity of this clone to variations in the environment.

In the rainy period, the increment in ET values of the IPA Sertânia clone was associated to $\Delta \mathrm{A}$ increase $\left(\mathrm{R}^{2}=0.75\right)$, when the CAI still presented small magnitude (continuous lines, Figure $4 \mathrm{C}$ ). This clone has an erect growth habit, unlike the two other, which have greater lateral growth (Silva et al., 2014). Moreover, the CAI evolution was slower during water availability periods, leading to a higher contribution of the evaporation component than of the transpiration component on the ET of this clone. Han \& Felker (1997) found that the evaporation component can represent, on average, $45 \%$ of ET, but varies over time with the soil cover index. This trend was not observed for the Orelha de Elefante Mexicana and Miúda clones. 


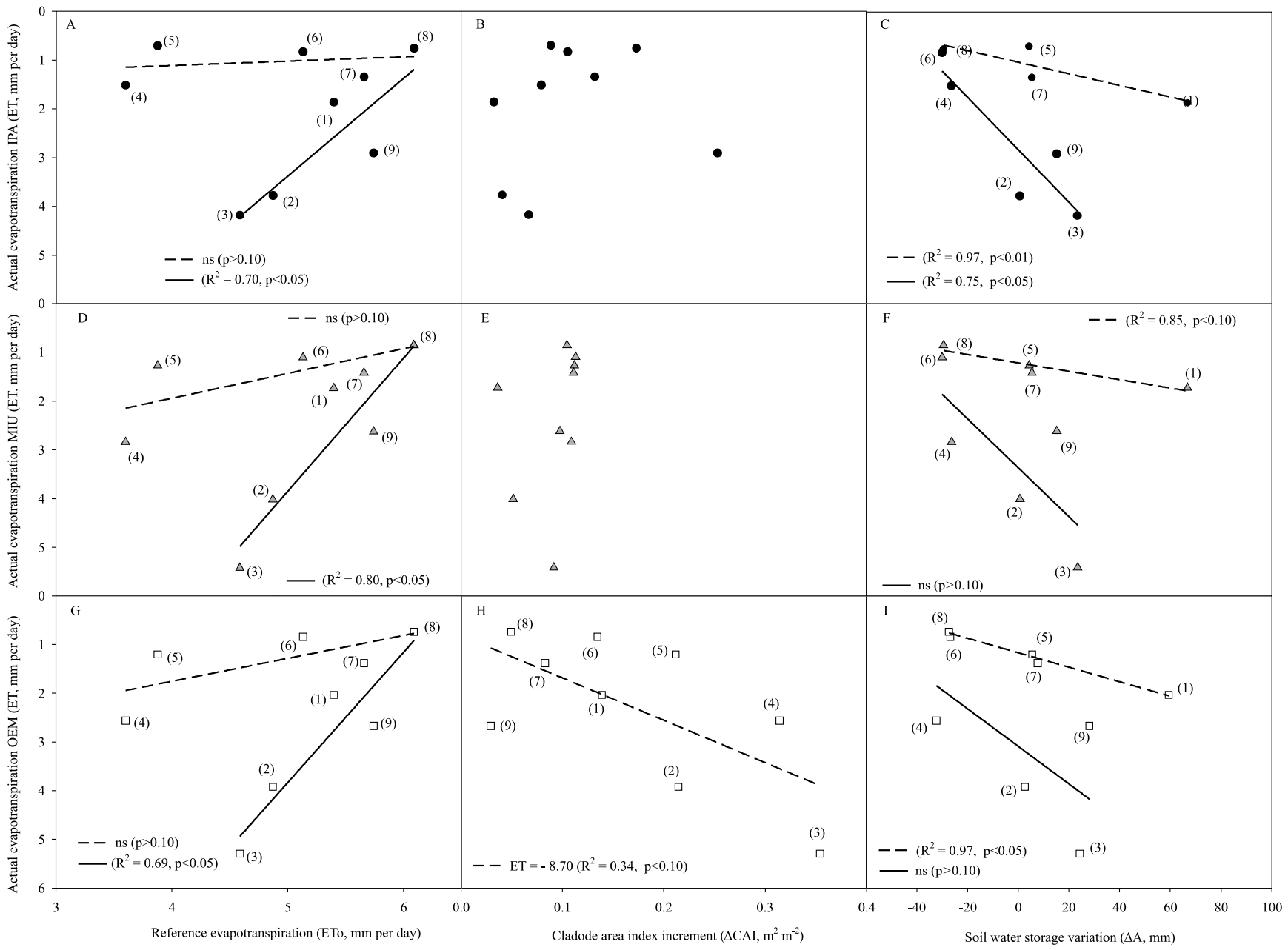

Figure 4. Relationship between the actual evapotranspiration(ET) during the studied period and the reference evapotranspiration $\left(\mathrm{ET}_{\mathrm{o}}\right)$ of the evaluated forage cactus clones, cladode area index increment $(\triangle \mathrm{CAI})$, and soil water storage variation $(\Delta \mathrm{A})$ during the experimental period of 499 days, divided into nine periods (in parenthesis). Dashed lines represent lower soil water availability; and continuous lines, higher soil water availability. Period 1, from October $20^{\text {th }}, 2010$, to December $15^{\text {th }}, 2010$; period 2, from December $16^{\text {th }}, 2010$, to February $9^{\text {th }}$, 2011; period 3, from February 10 ${ }^{\text {th }}$, 2011, to April $18^{\text {th }}$, 2011; period 4,

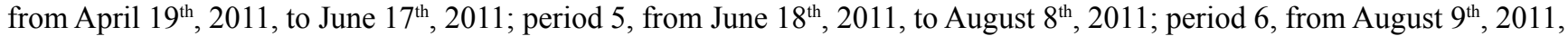
to September 26 ${ }^{\text {th }}$, 2011; period 7, from September 27 ${ }^{\text {th }}, 2011$, to November $14^{\text {th }}, 2011$; period 8, from November $15^{\text {th }}, 2011$, to January $4^{\text {th }}, 2012$; and period 9 , from January $5^{\text {th }}, 2012$, to March $2^{\text {nd }}, 2012$. The values of ET, $\Delta C A I$, and $\Delta A$ are averages of three replicates. IPA, IPA Sertânia; MIU, Miúda; and OEM, Orelha de Elefante Mexicana.

\section{Conclusions}

1. Water dynamics in soil cultivated with the three evaluated clones of forage cactus under rainfed conditions, in the semiarid region of Brazil, are similar, resulting in similar water consumption.

2. Atmospheric demand controls the evapotranspiration of the evaluated clones only in higher soil water availability, whereas, in this condition, the water consumption of the Miúda clone decreases more rapidly with the increase of atmospheric demand.

3. The increment of the cladode area index increases the water consumption of the Orelha de Elefante Mexicana clone.

4. The Miúda clone presents lower plasticity to soil water availability than the others clones in dry conditions. 


\section{Acknowledegments}

To Conselho Nacional de Desenvolvimento Científico e Tecnológico (CNPq, process 475279/20107) and to Fundação de Amparo à Ciência e Tecnologia do Estado de Pernambuco (Facepe, process APQ0215-01/10), for financial support; and to Coordenação de Aperfeiçoamento de Pessoal de Nível Superior (Capes), for scholarship granted.

\section{References}

ACEVEDO, E.; BADILLA, I.; NOBEL, P.S. Water relations, diurnal acidity changes, and productivity of a cultivated cactus, Opuntia ficus-indica. Plant Physiology, v.72, p.775-780, 1983. DOI: $10.1104 /$ pp.72.3.775.

ALLEN, R.G.; PEREIRA, L.S.; RAES, D.; SMITH, M. Crop evapotranspiration: guidelines for computing crop water requirements. Rome: FAO, 1998. 300p. (FAO Irrigation and Drainage Paper, 56).

AZEVEDO, P.V. de; SOUZA, C.B. de; SILVA, B.B. da; SILVA, V.P.R. da. Water requirements of pineapple crop grown in a tropical environment, Brazil. Agricultural Water Management, v.88, p.201-208, 2007. DOI: 10.1016/j.agwat.2006.10.021.

CASTELlANOS, M.T.; CARTAGENA, M.C.; RIBAS, F.; CABELLO, M.J.; ARCE, A.; TARQUIS, A.M. Impact of nitrogen uptake on field water balance in fertirrigated melon. Agricultural Water Management, v.120, p.56-63, 2013. DOI: 10.1016/j. agwat.2012.10.020.

CONSOLI, S.; INGLESE, G.; INGLESE, P. Determination of evapotranspiration and annual biomass productivity of a cactus pear [Opuntia ficus-indica L.(Mill.)] orchard in a semiarid environment. Journal of Irrigation and Drainage Engineering, v.139, p.680-690, 2013. DOI: 10.1061/(ASCE)IR.1943-4774.0000589.

CUSHMAN, J.C. Crassulacean acid metabolism. A plastic photosynthetic adaptation to arid environments. Plant Physiology, v.127, p.1439-1448, 2001. DOI: 10.1104/pp.010818.

DUBROVSKY, J.G.; NORTH, G.B.; NOBEL, P.S. Root growth, developmental changes in the apex, and hydraulic conductivity for Opuntia ficus-indica during drought. New Phytologist, v.138, p.75-82, 1998. DOI: 10.1046/j.1469-8137.1998.00884.x.

GAISER, T.; BARROS, I. de; LANGE, F.-M.; WILLIAMS, J.R. Water use efficiency of a maize/cowpea intercrop on a highly acidic tropical soil as affected by liming and fertilizer application. Plant and Soil, v.263, p.165-171, 2004. DOI: 10.1023/B:PLSO.0 000047733.98854.9f.

GHIBERTO, P.J.; LIBARDI, P.L.; BRITO, A.S.; TRIVELIN, P.C.O. Components of the water balance in soil with sugarcane crops. Agricultural Water Management, v.102, p.1-7, 2011. DOI: 10.1016/j.agwat.2011.09.010.

GOLDSTEIN, G.; ORTEGA, J.K.E.; NERD, A.; NOBEL, P.S. Diel patterns of water potential components for the Crassulacean acid metabolism plant Opuntia ficus-indica when well-watered or droughted. Plant Physiology, v.95, p.274-280, 1991. DOI: 10.1104/pp.95.1.274.

HAN, H.; FELKER, P. Field validation of water-use efficiency of the CAM plant Opuntia ellisiana in south Texas. Journal of Arid Environments, v.36, p.133-148, 1997. DOI: 10.1006/ jare.1996.0202.

INSTITUTO NACIONAL DE METEOROLOGIA (Brasil). INMET - Instituto Nacional de Meteorologia. Disponível em: $<$ http://www.inmet.gov.br/portal/>. Acesso em: 15 jan. 2015.

LIBARDI, P.L. Dinâmica da água no solo. São Paulo: Editora da Universidade de São Paulo, 2005. 335p.

LIMA, J.R. de S.; ANTONINO, A.C.D.; LIRA, C.A.B. de O.; SOUZA, E.S. de; SILVA, I. de F. da. Balanço de energia e evapotranspiração de feijão caupi sob condições de sequeiro.

Revista Ciência Agronômica, v.42, p.65-74, 2011. DOI: 10.1590/ S1806-66902011000100009.

MOCKUS, V. Design hydrographs. In: UNITED STATES DEPARTMENT OF AGRICULTURE. Natural Resources Conservation Service. National engineering handbook: part 630 hydrology. Washington: USDA, 1972. 115p.

MOURA, M.S.B. de; GALVINCIO, J.D.; BRITO, L.T. de L.; SOUZA, L.S.B. de; SÁ, I.I.S.; SILVA, T.G.F. da. Clima e água de chuva no semi-árido. In: BRITO, L.T.L.; MOURA, M.S.B. de; GAMA, G.F.B. (Ed.). Potencialidades da água de chuva no Semiárido brasileiro. Petrolina: Embrapa Semiárido, 2007. p.37-59.

OLIVEIRA, F.T. de; SOUTO, J.S.; SILVA, R.P. da; ANDRADE FILHO, F.C. de; PEREIRA JÚNIOR, E.B. Palma forrageira: adaptação e importância para os ecossistemas áridos e semiáridos. Revista Verde de Agroecologia e Desenvolvimento Sustentável, v.5, p.27-37, 2010.

PINHEIRO, K.M.; SILVA, T.G.F. da; CARVALHO, H.F. de S.; SANTOS, J.E.O.; MORAIS, J.E.F. de; ZOLNIER, S.; SANTOS, D.C. dos. Correlações do índice de área do cladódio com características morfogênicas e produtivas da palma forrageira. Pesquisa Agropecuária Brasileira, v.49, p.939-947, 2014. DOI: 10.1590/S0100-204X2014001200004.

PRIMO, J.T. de A.; SILVA, T.G.F. da; SILVA, S.M.S. e; MOURA, M.S.B. de; SOUZA, L.S.B. de. Calibração de sondas capacitivas, funções físico-hídricas e variação do armazenamento de água em um argissolo cultivado com palma forrageira. Revista Ceres, v.62, p.20-29, 2015. DOI: 10.1590/0034-737X201562010003.

SAN JOSÉ, J.; MONTES, R.; NIKONOVA, N. Diurnal patterns of carbon dioxide, water vapour and energy fluxes in pineapple [Ananas comosus (L.) Merr. cv. Red Spanish] field using eddy covariance. Photosynthetica, v.45, p.370-384, 2007a. DOI: 10.1007/s11099-007-0064-7.

SAN JOSÉ, J.; MONTES, R.; NIKONOVA, N. Seasonal patterns of carbon dioxide, water vapour and energy fluxes in pineapple. Agricultural and Forest Meteorology, v.147, p.16-34, $2007 \mathrm{~b}$. DOI: 10.1016/j.agrformet.2007.06.003.

SANTOS, H.G. dos; JACOMINE, P.K.T.; ANJOS, L.H.C. dos; OLIVEIRA, V.A. de; OLIVEIRA, J.B. de; COELHO, M.R.; LUMBRERAS, J.F.; CUNHA, T.J.F. (Ed.). Sistema brasileiro de classificação de solos. 2.ed. Rio de janeiro: Embrapa Solos, 2006. 306p. 
SCHWARTZ, R.C.; BAUMHARDT, R.L.; EVETT, S.R. Tillage effects on soil water redistribution and bare soil evaporation throughout a season. Soil and Tillage Research, v.110, p.221-229, 2010. DOI: 10.1016/j.still.2010.07.015.

SILVA, T.G.F. da; MIRANDA, K.R. de; SANTOS, D.C. dos; QUEIROZ, M.G. de; SILVA, M. da C.; CRUZ NETO, J.F. da; ARAÚJO, J.E.M. Área do cladódio de clones de palma forrageira: modelagem, análise e aplicabilidade. Agrária, v.9, p.633-641, 2014. DOI: 10.5039/agraria.v9i4a4344.

SILVA, T.G.F. da; MOURA, M.S.B. de; ZOLNIER, S.; SOARES, J.M.; VIEIRA, V.J. de S.; FARIA JÚNIOR, W.G. Requerimento hídrico e coeficiente de cultura da cana-de-açúcar irrigada no semiárido brasileiro. Revista Brasileira de Engenharia Agrícola e Ambiental, v.16, p.64-71, 2012. DOI: 10.1590/ S1415-43662012000100009.

SNYMAN, H.A. A greenhouse study on root dynamics of cactus pears, Opuntia ficus-indica and O. robusta. Journal of Arid Environments, v.65, p.529-542, 2006b. DOI: 10.1016/j. jaridenv.2005.10.004.
SNYMAN, H.A. Root distribution with changes in distance and depth of two-year-old cactus pears Opuntia ficus-indica and $O$. robusta plants. South African Journal of Botany, v.72, p.434-441, 2006a. DOI: 10.1016/j.sajb.2005.12.008.

TAIZ, L.; ZEIGER, E. Fisiologia vegetal. 4.ed. Porto Alegre: Artmed, 2009. 819p.

THORNTHWAITE, C.W.; MATHER, J.R. The water balance. Centerton: Drexel Institute of Technology, 1955. 104p. (Publications in climatology, v.8, n.1).

YADAV, S.; HUMPHREYS, E.; KUKAL, S.S.; GILL, G.; RANGARAJAN, R. Effect of water management on dry seeded and puddled transplanted rice: Part 2: Water balance and water productivity. Field Crops Research, v.120, p.123-132, 2011. DOI: 10.1016/j.fcr.2010.09.003.

ZOUGMORÉ, R.; MANDO, A.; STROOSNIJDER, L. Effect of soil and water conservation and nutrient management on the soil-plant water balance in semi-arid Burkina Faso. Agricultural Water Management, v.65, p.103-120, 2004. DOI: 10.1016/j. agwat.2003.07.001.

Received on January 22, 2015 and accepted on May 26, 2015 